DOI.

https://doi.org/10.22219/fths.v2i2

Received: Mei 2019

Accepted: June 2019

Available online: July 2019

\title{
Study of Physical Characteristic, Water Vapor Transmission Rate and Inhibition Zones of Edible Films from Aloe vera (Aloe barbadensis) Incorporated with Yellow Sweet Potato Starch and Glycerol
}

\author{
Nur Rahmiatiningrum ${ }^{1}$, Warkoyo $^{1 *}$, Sukardi ${ }^{1}$ \\ ${ }^{1}$ Department of Food Technology, Faculty of Agriculture and Animal Science, University of \\ Muhammadiyah Malang, Malang, Indonesia \\ *Coresponding author email : warkoyo@umm.ac.id
}

\begin{abstract}
Glucomannan was the main polysaccharide of Aloe vera gel. It was dissolved in water, formed gel and transparent as a film. Aloe vera gel was reported antimicrobial and antioxidant activity such as saponin and anthraquinone that was potential for the increased value of an edible film. However, Aloe vera gel form weak film caused glucomannan had high water absorption. In this research Aloe vera gel was used as a basis of polymer film. Yellow sweet potato starch added for the strength matrix component used amylose. This starch expected to give colors from carotenoids. Glycerol also added for the flexibility of an edible film. Randomized Complete Block Design Factorial (RCBD) was applied. The first factor was concentration of yellow sweet potato starch $(1 \%, 2 \%, 3 \%)$ and the second one was glycerol $(0.1 \%, 0.25 \%$, and $0.5 \%)$. The parameters tested were color, thickness, transparency, tensile strength, elongation, solubility, water vapor transmission rate, and inhibition zones against $E$. coli, and $S$. aureus, fungi $A$. niger and $C$. albicans. The results showed that the addition of yellow sweet potato starch and glycerol with different concentration had a significant effect on color, thickness, transparency, tensile strength, elongation, and solubility. However, edible film on this research has not to show bacteria and fungi inhibition zone of edible film. P2G1 as a best treatment (yellow sweet potato starch $2 \%$ and glycerol $0.1 \%$ ) produced edible film with a thickness of $0.12 \mathrm{~mm}$, elongation $50.85 \%$, tensile strength 0.55 $\mathrm{MPa}$, solubility $41.03 \%$, transparency $2.13 \%$, vapor transmission rate $3.40 \mathrm{~g} / \mathrm{m} 2 / 24 \mathrm{hours}$, $\mathrm{L}, \mathrm{a}+, \mathrm{b}+$ score in sequence $41.87,0.2$, and 4.1 .
\end{abstract}

Keywords : Aloe vera gel, edible film, glycerol, starch

\section{INTRODUCTION}

Biodegradable packaging in the form of thin coating, composed of the components of a suitable polymer consumption known as edible film. The main function is edible film as a barrier to gas, oil and water so as to keep the product packaged from damage. Innovation in edible film is aimed at improving the physical properties, mechanics and barrier as well as providing added value from the content of antimicrobial compounds. The international standard value of edible film (JIS, 1975) is the thickness of $<0.25 \mathrm{~mm}$, tensile strength $\geq 0.39 \mathrm{MPa}$, 
elongation (< 10\% Bad; 10-50\% good; > 50\% very good) and water vapor rate transmission (WVTR) $<7$ g per $\mathrm{m}^{2}$ per day.

The high yield of Aloe barbadensis gel is often utilized in various processed products (Pohan, 2017). The main polysaccharide of the Aloe Vera gel is a water soluble glucomate, which can form a gel and be transparent if it is in the form of a film (Thomas, 1997). In addition, Aloe Vera naturally also has antimicrobial compounds and antioxidants such as saponins as well as antraquinone that are potential to optimize the role of edible film. The application of edible film from Aloe Vera gel with the addition of glycerol $0.5 \%(\mathrm{v} / \mathrm{v})$ produce edible which is not bitter, not fragile, brightly colored, and well textured, thickness $0.076 \mathrm{~mm}$, tensile strength 6.3 $\mathrm{MPa}$ as well as WVTR $906.65 \mathrm{~g}$ per $\mathrm{m}^{2}$ per day (Arifin, 2016). The WVTR value is still not compliant with international standards. In addition, the ability to water absorption by a large glucomanan caused the film to be soft. It makes the need for the addition of film matrix polymer. The more starch added will form a more complex and dense film matrix assuming it can improve the physical, chemical and barrier properties better.

Oduro et al., (2000) stated that the sweet potato starch had amyc levels ranging between $8.50-37,40 \%$. In addition, the yellow sweet potato starch contains B-caroten $2900 \mathrm{mg} / 100 \mathrm{~g}$ (Murtiningsih and Suyanti, 2011) that give a distinctive orange or yellow color.

Potential material above makes the opportunity to held the research of the production of edible film with the addition of yellow sweet potato starch and glycerol. Research is expected to improve the physical properties and the barrier to moisture from the addition of yellow yam and glycerol starch. The study also identified the active compound role of Aloe Vera gel base against the resistance of Eschericia coli, Staphylococcus aureus, Aspergillus niger and Candida albicans.

\section{RESEARCH METHODS \\ Materials}

The materials included Aloe barbadens which purchased from Ngaglik Batu city, yellow sweet potato in Batu market supplied from Pare, Escherichia coli, Aspergillus Niger and Candida albicans from Biomedical Laboratory of University of Muhammadiyah Malang, Staphylococcus aureus from Food Safety Laboratory and quality control of Brawijaya University, Malang.

\section{Equipmnets}

The equipments used in this research were autoclave, Ohauss digital analytic scales, hot plate strirrer, micrometer screw, color reader, Cabinet dryer, Oven, Texture Analyzer, Laminary Air Flow, micropipet.

\section{Aloe Vera Gel preparation}

Aloe Gel was obtained by soaking the flesh of Aloe vera on aquades 1:2 for 15 minutes. 


\section{Yellow starch preparation}

The making of yellow yam starch was done by precipitation the suspension for 24-hour and continued by drying with temperature of $50^{\circ} \mathrm{C}$ for 5 hours.

\section{Edible Film production}

The process of edible film began with homogenization of yellow sweet potato starch according to the treatment of Aloe Vera $300 \mathrm{ml}$. Then the suspension was heated to $60{ }^{\circ} \mathrm{C}$. After heating for \pm 15 minute, glycerol added. It aimed to accelerate the interaction of polymer chains in the bind because of the increased kinetic energy and reach the temperature of starch gelatinization. The heating process was done when maintained the temperature reaches $85^{\circ} \mathrm{C}$ for \pm 15 minutes. The edible suspension then cooled at room temperature, followed by pour into tray and dried in the cabinet dryer $60^{\circ} \mathrm{C}$ for 24 hours.

\section{Research Parameter}

The edible film analysis included colour, thickness, transparency, film solubility, percent enlargement and strong film tensile, WVTR and an edible zone of the film against the Escherichia coli and Staphylococcus aureus and Aspergillus Niger and Candida albicans.

\section{Research Method and Data Analysis}

This method design used a two-factor and three times repetation. The first factor was the concentration of yellow sweet potato starch $(1 \% \mathrm{~b} / \mathrm{v}, 2 \% \mathrm{~b} / \mathrm{v}, 3 \%$ $\mathrm{b} / \mathrm{v})$. The second was the concentration of glycerol as a plasticizer $(0.1 \% \mathrm{v} / \mathrm{v}$, $0.25 \% \mathrm{v} / \mathrm{Vv}$ and $0.5 \% \mathrm{v} / \mathrm{v}$ ). Data analyzed by Analysis of variance (ANOVA) to know influence of treatment. Furthermore, if the effect is then continued with the Duncan's test with $\alpha=5 \%$.

\section{RESULTS AND DISCUSSION}

\section{Yellow Sweet potato starch}

The addition of sweet potato starch served as a constituent component of film matrix. The role of the amylose becomes one of the indications of edible film formation. Yellow sweet potato starch contained moisture about 16.79\%, accordance with Tian et al (1991) that showed the moisture of sweet potato starch is $11-17 \%$. Yellow sweet potato starch used in this study categorized as high amylose (> 25\%) with a rate of $35.54 \%$ wet based or $40.65 \%$ dry based.

The amylose of this research is also higher than Retnaningtyas (2014) that just has $27.70 \%$. The amyose structure in starch allows the formation of its constituent glucose intermolecular hydrogen bonds and a three-dimensional tissue during heating that can trap water resulting in a strong gel. 


\section{Thickness of Edible Film}

The thickness of edible film is one of the important characteristics to determine the feasibility of the edible film and also affects the application on the product. The results showed an interaction $(p \leq 0.05)$ between concentrations of yellow sweet potato starch and glycerol on the thickness of edible film. The lowest thickness of edible film was $0.08 \mathrm{~mm}$ at the P1G1 and the highest was $0.20 \mathrm{~mm}$ P3G3. The value indicates that the edible gel base of Aloe Vera with the addition of yellow sweet potato starch and glycerol meets JIS Standard (1997).

The thickness of this research is higher than Arifin et al (2016) that studied the $0.1 \%$ and $0.5 \%$ glycerol in Aloe Gel edible film produce thickness 0.076 and $0.089 \mathrm{~mm}$, respectively. Other research showed that the thickness of edible film with addition of Aloe Vera gel $300 \mathrm{ml}, 30 \mathrm{~g} / \mathrm{l}$ banana starch, chitosan $20 \mathrm{~g} / \mathrm{L}$ and sorbitol $10 \mathrm{~g} / \mathrm{L}$ amounted to $0.135 \mathrm{~mm}$ (Pinzon, 2018).

The $3 \%$ of starch in this study resulted thick and more rigid edible than others. This is made possible by the saturated suspension against starch content, resulting in the role of glycerol to improve low film flexibility. It is strengthened with the opinion of Pinzon et al, (2018) that the matrix component of an edible film complex may decrease the plastility of sorbitol.

\section{Colors Intensity of Edible Film}

The edible color of the film becomes the first judgment against the appearance or physical properties of the edible film. In addition, this aspect also affect the performance of the packaged product. The $\mathrm{L}$ value indicates the brightness level based on white. The positive of a value represent redness, while positive of b value is yellowness (Putri, 2012).

The results showed an interaction $(p \leq 0.05)$ between both factors on the brightness ( $\mathrm{L}$ ) of edible film. The highest $\mathrm{L}$ value indicates a brighter film, obtained in the P1G1 (43.53) while the low L value signifies an increasingly dark film, derived at P3G3 that has 40.13. These results indicate that with the addition of yellow sweet potato starch and glycerol can decrease the brightness value of the edible film.

The measurement results by using the color reader show a positive value against all the samples indicating that the edible film is reddish. A positive value obtained from 0.1-0.6. The results also showed an interaction $(\mathrm{p} \leq 0.05)$ between concentrations of yellow sweet potato starch and glycerol against a positive value of a. The added concentration of yellow sweet potato starch and glycerol increases the redness of the edible film.

The positive B value of all samples showed that the edible film is yellowish that ranged from 3.3 to 7.2. The results also showed an interaction ( $p \leq 0.05$ ) between both factors on a positive $\mathrm{B}$ value. The decrease in the $\mathrm{L}$ (brightness) is followed by an increase in the value of $a+$ and $b+$ along with the addition of 
yellow starch potato starch and glycerol. It is related to the existence of carotenoids in yellow sweet potato starch that is able to provide reddish color. Carotenoids are a group of natural pigments and antioxidants that lead to orange and red yellow in plants (Murtiningsih and Suyanti, 2011).

\section{Transparency Edible Film}

The transparency of the film provides information regarding the particle size dispersed in the matrix (Kampeerapappun et al., 2007). The transparency value indicates the clarity of the film, the lower the transparency value, the clearer the film. The results showed an interaction $(p \leq 0.05)$ between concentrations of yellow sweet potato starch and glycerol on the transparency of edible film. The value of transparency increases with the increasing concentration of yellow sweet potato starch and glycerol.

The yellow sweet potato starch gives a yellowish or orange red color to the film. The more component dissolved solids causing the formation of increasingly complex matrices, increasing the thickness so that transparency increases. The high value of transparency indicates edible blurring or decreased clarity.

Table 1. The Thickness, Transparency and Color Intensity of Edible Film

\begin{tabular}{lccccc}
\hline $\begin{array}{c}\text { Treatment } \\
(\text { Starch\%; Glycerol \%) }\end{array}$ & $\begin{array}{c}\text { Thickness } \\
(\mathrm{mm})\end{array}$ & $\begin{array}{c}\text { Transparency } \\
\left(\mathrm{A}_{546} / \mathrm{mm}\right)\end{array}$ & $\mathrm{L}$ & $\mathrm{a}^{+}$ & $\mathrm{b}^{+}$ \\
\hline P1G1 $(1 \% ; 0,1 \%)$ & $0.08^{\mathrm{a}}$ & $1.72^{\mathrm{a}}$ & $43.53^{\mathrm{e}}$ & $0.1^{\mathrm{a}}$ & $3.3^{\mathrm{a}}$ \\
P1G2 $(1 \% ; 0,25 \%)$ & $0.09^{\mathrm{b}}$ & $1.74^{\mathrm{a}}$ & $43.13 \mathrm{~d}^{\mathrm{e}}$ & $0.1^{\mathrm{a}}$ & $3.5^{\mathrm{b}}$ \\
P1G3 $(1 \% ; 0,5 \%)$ & $0.11^{\mathrm{c}}$ & $1.80^{\mathrm{b}}$ & $42.93^{\mathrm{d}}$ & $0.2^{\mathrm{b}}$ & $3.7^{\mathrm{ab}}$ \\
P2G1 $(2 \% ; 0,1 \%)$ & $0.12^{\mathrm{d}}$ & $2.13^{\mathrm{c}}$ & $41.87^{\mathrm{c}}$ & $0.2^{\mathrm{b}}$ & $4.1^{\mathrm{ab}}$ \\
P2G2 $(2 \% ; 0,25 \%)$ & $0.13^{\mathrm{e}}$ & $2.19^{\mathrm{d}}$ & $41.53^{\mathrm{bc}}$ & $0.3^{\mathrm{c}}$ & $4.2^{\mathrm{b}}$ \\
P2G3 $(2 \% ; 0,5 \%)$ & $0.14^{\mathrm{f}}$ & $2.23^{\mathrm{d}}$ & $41.20^{\mathrm{b}}$ & $0.4^{\mathrm{c}}$ & $4.9^{\mathrm{c}}$ \\
P3G1 $(3 \% ; 0,1 \%)$ & $0.17^{\mathrm{g}}$ & $2.31^{\mathrm{e}}$ & $40.80^{\mathrm{b}}$ & $0.5^{\mathrm{cd}}$ & $5.4^{\mathrm{c}}$ \\
P3G2 $(3 \% ; 0,25 \%)$ & $0.18^{\mathrm{h}}$ & $2.37^{\mathrm{f}}$ & $40.70^{\mathrm{b}}$ & $0.5^{\mathrm{d}}$ & $5.0^{\mathrm{c}}$ \\
P3G3 $(3 \% ; 0,5 \%)$ & $0.20^{\mathrm{i}}$ & $2.38^{\mathrm{f}}$ & $40.13^{\mathrm{a}}$ & $0.6^{\mathrm{e}}$ & $7.2^{\mathrm{d}}$ \\
\hline
\end{tabular}

The numbers followed by the same letter indicate a difference that is not as distinct (5\%) Based on the DMRT test.

\section{Solubility of Edible Film}

Solubility is one of the physical properties of edible film that shows the percentage of dissolved dry weight after being dipped in water for 24 hours. The dissolubility of the film is determined by the source of the film. The result showed an interaction $(\mathrm{p} \leq 0.05)$ between yellow sweet potato starch and glycerol on the solubility of film.

The addition of starch is able to lower film solubility. It was strengthened with the results of Warkoyo, et al (2014) that states an edible solubility in water will decrease with the increase in starch resulting from increased starch ratio, 
glycerol-starch ratio and decreased the hydrophilic group of edible film materials. The increased concentration of glycerol has no obvious effect on film solubility. It is possible that the low range of the concentration of glycerol $(0.1 \%, 0.25 \%$ and $0.5 \%)$. Glycerol as plasticizer is soluble in water according (Winarno, 1997). Glycerol can increase the adsorption of polar molecules such as water.

\section{Tensile Strength of Edible Film}

The tensile strength is a measure for the power of the film from the maximum pull until the film persists before tears. The results showed an interaction $(\mathrm{p} \leq 0.05)$ between yellow sweet potato starch and glycerol against a tensile strenght edible film. The tensile strength of the edible film increases along with the addition of yellow sweet potato starch and glycerol. The highest tensile strength is in the P3G3 with a value of $1.522 \mathrm{MPa}$ that is higher than the edible film with $8 \%$ of sweet potato and $2 \%$ glycerol about $1.3 \mathrm{MPa}$ (Ginting and Yulianti, 2012).

Yellow sweet potato starch has a high amylose about $35.54 \%$ wet based. The higher amylose, the greater tensile strength gets, because the more number of polymers in the matrix formation. The bond between the polymers is getting stronger so the tensile strength is also increasingly greater (Warkoyo et al, 2014).

\section{The Elongation of Edible Film}

Elongation is a change in the maximum length in the event of a stretch until the sample of the film tears. There is an interaction $(p \leq 0.05)$ between both factors. The average of elongation in this study did not meet JIS standards (1997) that just elongated $<10 \%$, ranged from $3.12 \%$ to $8.6 \%$. While the standart of elongation in edible films ranged from $15.55 \%$ to $50.85 \%$. However, the elongation of this research is higher than Ginting and Yulianti (2012) that studied the edible film with $8 \%$ sweet potato and $2 \%$ glycerol that just elongated $2.0 \%$.

The addition of $3 \%$ yellow sweet potato starch resulted a thick and more rigid edible than 1 and $2 \%$. Anandito, et al., (2012), stated that the increase of the material leads to a decrease in the ratio of glycerol as plasticizer to starch, resulting in decreased film elongation, which then causing the film to break easily. These cross-bonds trigger a more rigid film formation. Giterrez and Gonzalez (2017) also stated that an increase in the concentration of polyphenols from Aloe Vera Gel in the edible film with banana flour -glycerol cause a cross bond between the starch molecules.

\section{Water Vapor Transmission Rate (WVTR) of Edible Film}

WVTR is the amount of moisture that through a broad unity surface or slope amount of water vapor divided area (Liu and Han, 2005). ASTM E96 is known as a gravimetric method or a ' cup test ' method used to calculate the 
transmission rate of moisture passing through the barrier film. This method is based on the principle of desiccant and water. The desiccant will absorb moisture entering through an edible film gap. The more moisture absorbed, the higher the film permeability to moisture.

The results showed an interaction $(\mathrm{p} \leq 0.05)$ between both factors against the WVTR. The WVTR of this research has fulfilled the International Standard of ( $<7$ g per $\mathrm{m}^{2}$ per day) that ranged from 2.61 to $4.09 \mathrm{~g}$ per $\mathrm{m}^{2}$ per day. The WVTR decreases when increases yellow sweet potato starch and glycerol. The phenomenon is supported by Liu and Han's (2005) that the hydrophilic film shows a positive corelation between the thickness and permeability of moisture. The larger the dissolved polymer, the thicker of edible film formed, so it has a good role as the barrier (Gontard, 2003).

Table 2. The Solubility, Tensile Strength, Elongation and WVTR of Edible Film

\begin{tabular}{|c|c|c|c|c|}
\hline $\begin{array}{l}\text { Treatment } \\
\text { (Starch\%;Glycerol \%) }\end{array}$ & $\begin{array}{l}\text { Solubility } \\
(\%)\end{array}$ & $\begin{array}{l}\text { Tensile } \\
\text { Strength } \\
(\mathrm{MPa})\end{array}$ & $\begin{array}{l}\text { Elongation } \\
(\%)\end{array}$ & $\begin{array}{l}\text { WVTR (g } \\
\text { per } \mathrm{m}^{2} \text { per } \\
\text { day) }\end{array}$ \\
\hline P1G1 (1\%;0,1\%) & $53.89 \mathrm{ef}$ & $0.156^{\mathrm{a}}$ & $17.25^{\mathrm{ab}}$ & $4.09 \mathrm{e}$ \\
\hline P1G2 (1\% ; 0,25\%) & $54.93^{f}$ & $0.237^{b}$ & $15.55^{\mathrm{ab}}$ & $3.85^{\mathrm{de}}$ \\
\hline P1G3 $(1 \% ; 0,5 \%)$ & $56.65^{\mathrm{f}}$ & $0.353^{c}$ & $8.60^{\mathrm{a}}$ & $3.71^{\mathrm{d}}$ \\
\hline P2G1 $(2 \% ; 0,1 \%)$ & $41.03^{\mathrm{d}}$ & $0.555^{\mathrm{d}}$ & $50.85^{\mathrm{c}}$ & $3.40^{c}$ \\
\hline P2G2 $(2 \% ; 0,25 \%)$ & $46.43^{\mathrm{e}}$ & $0.722^{\mathrm{e}}$ & $25.09^{b}$ & $3.26^{\mathrm{c}}$ \\
\hline P2G3 $(2 \% ; 0,5 \%)$ & $49.20^{\mathrm{e}}$ & $0.875^{\mathrm{f}}$ & $22.69^{b}$ & $2.98^{b}$ \\
\hline P3G1 $(3 \% ; 0,1 \%)$ & $28.15^{\mathrm{a}}$ & $1.114^{\mathrm{g}}$ & $3.12^{\mathrm{a}}$ & $2.92^{b}$ \\
\hline P3G2 (3\%; 0,25\%) & $31.48^{b}$ & $1.376^{\mathrm{h}}$ & $4.11^{\mathrm{a}}$ & $2.88^{b}$ \\
\hline P3G3 $(3 \% ; 0,5 \%)$ & $35.38^{\mathrm{c}}$ & $1.522^{\mathrm{i}}$ & $6.60^{\mathrm{a}}$ & $2.61^{\mathrm{a}}$ \\
\hline
\end{tabular}

The numbers followed by the same letter indicate a difference that is not as distinct (5\%) based on the DMRT test.

\section{Barrier Zone of Edible Film}

The edible film of this research did not exhibit the presence of a inhibitory zone against the growth of Escherichia coli, Staphylococcus aureus, Aspergillus Niger and Candida albicans. It is perhaps due to the low content of antimicrobial compounds in film polymer. The decreaced of Aloe vera effectiveness as antimicrobial influenced by exposure to air of Aloe vera gel resulting in rapidly oxidized, decomposed and lose its biological activity.

The antibacterial activity not only comes from Aloe vera gel, but also other active compounds in the plant, because the polysaccharide in the gel is unstable to heat, acid, and enzyme (Rahardjo et al, 2017).

\section{CONCLUSION}

The best treatment met an International standard of edible film is P2G1 ( $2 \%$ yellow sweet potato starch and $0.1 \%$ glycerol) with a thickness of $0.12 \mathrm{~mm}$, 
elongation of $50.85 \%$, tensile strength of $0.55 \mathrm{MPa}$, the solubility of $41.03 \%$, transparency of $2.13 \%$, value $\mathrm{L}, \mathrm{a}+\mathrm{b}+$ of $41.87 ; 0.2$; And 4.1 , respectively as well as WVTR $3.40 \mathrm{~g}$ per $\mathrm{m}^{2}$ per day.

\section{REFERENCES}

Arifin, H. R., Setiasih, I. S., \& Hamdani, J. S. (2016). Pengaruh Penambahan Gliserol Terhadap Karakteristik Penyalut Edibel Gel Lidah Buaya (Aloe vera). Jurnal Aplikasi Teknologi Pangan, 5 (1): 6-9.

Ginting, E, Y. Widodo, S. A. Rahayuningsih and M. Jusuf. 2005. Karakteristik Pati Beberapa Varietas Ubi Jalar. Jurnal Penelitian Pertanian Tanaman Pangan, Vol. 24(1): 8-18.

Gontard, N., Guilbert., S., dan Cuq, J.L. 1993. Water and Glycerol as Plasticizer Affect Mechanical and Water Vapor Barrier Properties of an Edible Wheat Gluten Film. Journal Food Science. 58(1): 206 - 211.

Huri, D., dan Fitri C. 2014. The Effect of Glycerol and Aple Peel Waste Extract Concentration on Physical ad Chemical Characteristik of Edible Film. Jurnal Pangan dan Agroindustri 2(4): 29-40.

[JSA] Japanese Standart Association. 1997. JIS Z 1707: 1997 General Rules of Plastic Films for Food Packaging. Tokyo: JSA.

Kampeerapappun P., Aht-Ong D., Pentrakon D., dan Srikulkit K., 2007. Preparation of Cassava Starch/Montmorillonite Composite Film. Carbohydrate Polymers. 67:155-163.

Liu. Z. dan J. H Han. 2005. Film Forming Characteristics of Starches. Journal Food Science. 70(1):E31-E36.

Murtiningsih dan Suyanti. 2011. Membuat Tepung Umbi dan Variasi Olahannya. Jakarta: AgroMedia Pustaka.

Pinzon, Magda., Omar R Gracia., C. C. V. 2018. The influence of Aloe vera gel incorporation on the physicochemical and mechanical properties of bananastarch-chitosan edible film. Journal of Science and Agriculture, (June). https://doi.org/10.1002/jsfa.8915.

Putri, Anissa R. 2012. Pengaruh Jumlah Gula dan Asam Sitrat terhadap SIfat Organoleptik Kadar Air dan Jumlah Mikroba Manisan Kering Siwalan. Jurnal Boga (3):1.

Pohan, N. E. 2017. Uji Daya Terima Agar-Agar Kombinasi Lidah Buaya dengan Daun Afrika Selatan (Vernonia amygdalina Delie). Medan: Universitas Sumatera Utara.

Rahardjo, M., Koendhori E.B., dan Setiawati Y. 2017. Uji Efektifitas Antibekteri Etanol Lidah Buaya (Aloe vera) Terhadap Bakteri Staphlococcus aureus. Jurnal Kedokteran Syiah Kuala 17(2): 65-70.

Retnaningtyas D.A dan Putri W.D.R. 2014. Karakterisasi Sifat Fisikokimia Pati Ubi Jalar Oranye Hasil Modifikasi Perlakuan Lama Perendaman dan Konsentrasi STTP. Jurnal Pangan dan Agroindustri 2 (4): 68-77.

Tian, S.J., J.E. Rickard dan J.M.V. Blanshard. 1991. Physicochemical Properties of Sweet Potato Starch. Journal Science Food Agriculture 57: 459-491.

Thomas, W. R. 1997. Konjac Gum. In: A. Imeson, Ed. Thickening and Gelling Agents for Food, 2: 169-79, Blackie Academic and Professional London. 
Warkoyo, Rahardjo, B., Marseno D.W., Karyadi J.N.W. (2014). Sifat Fisik, Mekanik dan Barrier Edible Film Berbasis Pati Umbi Kimpul (Xanthosoma Sagittifolium ) yang Diinkorporasi. Jurnal Agritech, 34(1): 72-81.

Winarno , F.G. 1997. Kimia Pangan dan Gizi. Jakarta : Gramedia Pustaka Utama 